\title{
Petrogenetic Studies of the Basement Rocks in Jimgbe and Environs, Northcentral Nigeria
}

\author{
${ }^{* 1}$ L. M. Adamu, ${ }^{2}$ A. O. Umaru, ${ }^{1}$ T. S. Ereosun, ${ }^{3}$ M. Kitha, ${ }^{4}$ A. E. Aliyu \\ ${ }^{1}$ Department of Earth Sciences, Kogi State University, Anyigba, Kogi State, Nigeria \\ 2Department of Geology, University of Maiduguri, Maiduguri, Borno State, Nigeria \\ 3Department of Geology, Usumanu Danfodia University, Sokoto, Sokoto State, Nigeria \\ ${ }^{4}$ Department of Geology, Ahmadu Bello University, Zaria, Kaduna State, Nigeria \\ [ ${ }^{*}$ Corresponding Author: E-mail: lukman10musa@yahoo.com]
}

\section{ABSTRACT}

Geochemical and petrographic studies of Basement rock outcropped at southeastern Jimgbe have been carried out with the aim of characterizing and delineating the petrogenesis of the basement rocks. Field results with Facies analyses of the basement rocks in the study area revealed four (4) dominant rock units: Porphyritic granite, Migmatitic gneiss, Granite gneiss and Biotite gneiss. The minor rocks include quartzofeldspartic intrusion and quartz vein. The area has different structures such as fold, fracture and foliation which trends NW-SE and NE-SW direction, this is allotted to the Pan-African Orogeny imprints. Fourteen (14) analyzed for petrographic method and twenty-four (24) samples were analyzed for major elements using XRF geochemical method. The petrographic analysis result showed that the four rock types are granitic in origin due to their high quartz and feldspar contents. The major mineral compositions are quartz, plagioclase, microcline and biotite. Results of geochemical studies shows that the average oxide percentages are; $\mathrm{SiO}_{2}(69.25 \%), \mathrm{Al}_{2} \mathrm{O}_{3}(12.41 \%), \mathrm{CaO}(5.72 \%), \mathrm{Na}_{2} \mathrm{O}(3.25 \%), \mathrm{K}_{2} \mathrm{O}(3.76 \%), \mathrm{MgO}(2.76 \%)$, $\mathrm{Fe}_{2} \mathrm{O}_{3}(1.79 \%), \mathrm{TiO}_{2}(0.28 \%), \mathrm{MnO}(0.33 \%)$ and $\mathrm{P}_{2} \mathrm{O}_{5}(0.47 \%)$. These results showed that the rocks are calcic, and are also of high K-Calc alkaline in nature, the rocks majorly plot in the eugeosynclinal field except for sample T4 which plots in the sedimentary field. They are mostly S-type peraluminous rocks except for T11 which is an I-type peraluminous rock and all plot in the Granodioritic field.

Keywords: Precambrian; Southwestern Basement Complex; Mineralogy; Orogeny; Jimgbe; Ajaokuta

\section{INTRODUCTION}

The study area is located in the Southeastern Jimgbe area, part of Lokoja Sheet 247 SW of Kogi State, Nigeria. It is located between the latitude $07041^{\prime}-077^{\circ} 43^{\prime} \mathrm{N}$, and longitude $06^{\circ} 43^{\prime}$ - $06^{\circ} 45^{\prime} \mathrm{E}$ (Figure 1). The extent of the study area is $13.69 \mathrm{~km}^{2}$. The area is accessible through the Ajaokuta - Ganaja-Lokoja road which cuts across the North-Western part of the mapped area. Other minor roads are footpaths that links the settlements and the two dry stream channels running west to east of the study area to the Niger River. The footpaths helped in designing a suitable closed transverse method during mapping and also the dry stream channels helped in exposing the low lying outcrops for further field studies. The area has a tropical continental climate exhibiting the form of regional climate of the West Africa climate. There are two major seasons: The raining season which is between April and October and the Dry season which lasts between October and April. It also has an annual temperature of about $26-27^{\circ} \mathrm{C}$ (Ogbonna et al., 2006). The vegetation falls within the tropical or woodland and tall grass Savannah climate zone, which is influenced by two climatic conditions of rain and dry season. Having the most widespread savanna in Nigeria which is the Guinea savanna, it has a mean annual rainfall ranging from $100-200 \mathrm{~cm}^{2}$ or 29.4 Inch of precipitation annually.

The study encompasses specialties such as petrology, geochemistry and petrogenesis. Petrology is the branch of geology that studies the conditions under which rocks are being formed. It deals with origin and formation of rocks 


\section{Nigerian Journal of Basic and Applied Science (December, 2021), 29(2):46-58}

and therefore involves the laboratory synthesis of rocks for purpose of ascertaining the physical and chemical conditions (geochemistry) under which rock formation occurs. Petrographic study involves detailed descriptions of rocks with respect to its mineral content and its textural relationships within the rock. The petrographic analysis of any given rock(s) sample aid in the classification of that particular rock sample. Most Geology, Geochemistry and Petrogenetic studies of the Precambrian Basement Rocks around the Southwestern Basement Complex were carried out by workers such as Akindele and Goki et al., (2011), Onimisi et al. (2013), Folorunso et al. (2013), Olatunji et al. (2013), Olusiji (2015), Ogunyele et al. (2018), Adegbuyi et al. (2018) and Gideon, (2019) on a regional scale. Akindele and Oyinloye, (2011) revealed that of all the tectonic episodes, the Eburnean and the PanAfrican Orogeny are the major events which modified the study area and the Precambrian geology of Nigeria. His geological and geochemical results unraveled that all these crystalline rocks are genetically related and had evolved by progressive differentiation of a parent basaltic magma to give rise to the protoliths of the amphibolites. He concluded a back arc tectonic setting as the environment of emplacement of these rocks. Onimisi et al., (2013) revealed occurrence of two outcrops of marble (described as Mass I and Mass II) around Itobe. Also that the Itobe marble body and the host rocks of mica/quartz schist and quartzite trend in NNESSW direction; parallel to dominant foliation trend of the associated basement rocks. XRD analysis of the marble reveals an average mineralogical composition of Dolomites (33.3\%, Calcite $(64.9 \%)$ and Quartz (1.8\%) for mass I and dolomite (1.7\%), Calcite (92.5\%) and Quartz (6.3\%) for mass II.

Folorunso et al. (2013) revealed four different rock types: porphyroblastic (augen) gneiss, hornblende-biotite gneiss, banded gneiss and quartz schist with mineralogical assemblages ranging from quartz, micas (biotite and muscovite), hornblende, feldspars (plagioclase and microcline) feldspars to accessory and opaque minerals (iron oxide) in part of Ago-Iwoye Southwestern Nigeria and also revealed NW-SE trending of foliations and mineral lineation, which conforms to the direction of stream flow as an indication of the streams being structurally controlled. Olatunji et al., (2013) revealed that the basement rocks around Ganaja, Kogi State, Nigeria belongs to the Migmatite-gneiss complex of the southwestern basement complex and that the area is underlain predominantly by migmatite, augen gneiss, biotite gneiss, as well as minor occurrences of quartzo-feldspathic veins. Adegbuyi et al. (2018) revealed petrologic units around Oka-Akoko, Southwestern Nigeria include grey gneiss, granite gneiss, older granite, Charnokite and minor felsic and basic rocks. Petrographic results revealed that the granite gneiss is more enriched in Quartz and alkali feldspar than the grey gneiss while the grey gneiss is richer in plagioclase feldspar, hornblende, and opaques compared to the granite gneiss. They revealed igneous protoliths of granitic and granodioritic compositions, respectively for the Oka-Akoko granite gneiss and grey gneiss and further draw that the grey gneiss is ferroan, alkali to alkali-calcic and metaluminous, suggesting an igneous protoliths of M-type granite derived from melting of rocks from upper mantle to lower crustal regions under conditions of limited availability of water and a low oxygen fugacity while the granite gneiss is magnessian, alkali-calc and slightly peraluminous suggesting that its igneous protoliths(s) is an Itype granitoid derived from the partial melting of crustal igneous rocks. Gideon, (2019) revealed the lithologies within Okene Metropolis, North Central Nigeria to include Migmatite, granite, charnockite, hornblende biotite gneiss, melanocratic banded gneiss, and leucocratic biotite gneiss, quartzo-feldspartic gneiss and pegmatite dyke all of igneous origin and high alumina, alkaline and tholeitic composition.

Nevertheless, this research was conducted with the aim of determining the petrology, geochemical compositions and Petrogenetic 
characterization of the basement rocks around Jimgbe area. Hence, it documents the petrographical and geochemical study of the study area which include descriptions, identification and measurement of geologic structures in-situ rock outcrop, identification of various rock units, production of a detailed geologic map of the study area and delineate an inferred rock boundary between these rock types. The study also discloses the major rock forming minerals, the elemental composition of the different rock types as well as the textural relationships within the rock. The findings of this work will help in the understanding of the origin of the different lithologic units in the study area and genesis of the Basement Complex of the southwestern Nigeria.

\section{MATERIALS AND METHODS Field Methods}

The field methods include choosing a suitable open traverse method of mapping which involved traversing along routes and mapping out the outcrops megascopically, structural features on the outcrops and demarcating geological boundaries. The field work was carried out over a period of three weeks. This involved reconnaissance mapping, detailed geological mapping which include collection of representative rock samples from outcrops, from along river channels and road cuts. These rock were identified and studied on the field and the information such as the trend, extent, colour, structural characteristics and the location using the Global Positioning System (GPS) were all recorded in the field notebook. The mapping also involved recognition of contact relationship between the different rock types within the study area and the representation of each of the rock unit on the base map (Figure 1).

\section{Sampling and Sample Preparation}

Each of the samples collected were well labeled using masking tape taking note of the locations and structures such as joints, folds, veins, foliations etc. About thirty (30) rock samples were collected during mapping. Rocks were systematically sampled to represent the outcrops and to avoid weathered sample. At each sampling point, weathered surfaces were avoided, fresh representative rock samples were taken, packaged in new polythene sample bag and labeled.

\section{Thin Section Analysis}

Fourteen (14) rock samples were systematically selected from the thirty (30) sample from the study area and were cut for thin section preparation. The cutting was across the foliations so that all the minerals present in the rock will surface on the rock slide. The cut section of these rocks were frosted and placed on a glass slide with Canada balsam. The excess thickness of the rock was then grinded from the Frosting section of the Thin Section machine and then manually frosted on a flat surface using Carborundum so as to get a perfect and the required thickness of $0.003 \mu \mathrm{m}$ for a rock slide. The petrographic analysis was carried out in the Petrology laboratory, Department of Earth Sciences, Kogi State University, Anyigba, Nigeria. The thin sections were examined under the microscope using plane polarized light and cross nicols. The modal composition was then carried out to determine the mineralogical compositions of each sample.

\section{Geochemical Analysis (X-Ray Fluorescence X.R.F)}

Twenty-four (24) rock samples were subjected out of the thirty (30) total rock samples for geochemical analysis. Firstly, samples were taken to the sample preparation laboratory for pulverization for the geochemical analysis. The pulverizing machine ground the rock sample into fine grain form with crystals not more than $60 \mu \mathrm{m}$. The pulverized sample was measured and further made into pellets using deionized water. The pellet was then air-dried and introduced into the vacuum chamber of Energy Dispersion X-ray Fluorescence Spectrometer machine. The result is usually presented in form of Oxides and discriminate plots were produced. 


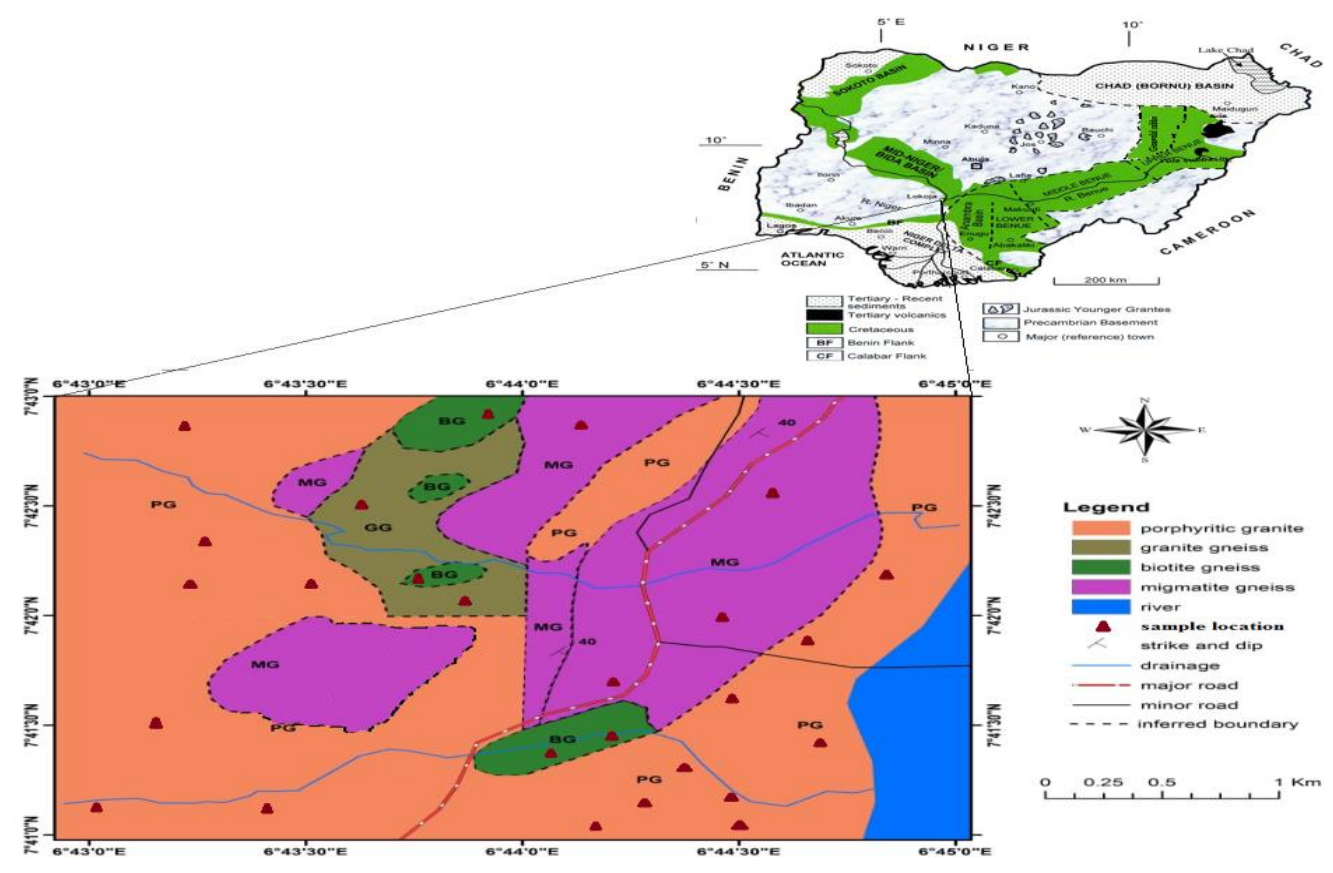

Figure 1: Geology and sample location map of the study area.

\section{RESULTS AND DISCUSSION}

\section{Petrology, Mineralogy and Field Relationships}

The study area is made up of porphyritic granite, migmatitic gneiss, granite gneiss and biotite gneiss and minor lithological units which include pegmatite, quartz vein and aplite dykes (Figure 1). The structural feature of the study area comprises joints, fold, joints and foliation.

\section{Porphyritic Granite}

The rock is light in colour and covers about $75 \%$ of the study area. The outcrop is generally low lying and extend towards the River Niger to form the base of the river (Figure 1). The rock has a porphyritic texture with phenocrysts composed ofcomposed of white to pink prismatic microcline (30 $\mathrm{mm}$ and sometimes up to $40 \mathrm{~mm}$ in length) (Figure 2). These porphyritic textures are randomly oriented in a medium to fine grained granitic groundmass. The minor rock includes cross cutting quartzo-feldspartic intrusions and quartz vein intrusions which is majorly composed of feldspar, quartz and biotite mica. The dominant mineral assemblages found in the porphyritic granite include Quartz (39.91\%), Plagioclase (13.2\%), Microcline (14.3\%), biotite (11.6\%), Muscovite (8.0\%), Hornblende (7.4\%), and Opaque Mineral (5.5\%) (Figure 3 ) and the structures found on the outcrop are microfolds, joints, faults, veinlets and exfoliation.

\section{Biotite Gneiss}

This rock type occurred as an isolated outcrop in the western part of the study area (Figure 1). The outcrop is trending $120^{\circ} \mathrm{ESE}$ and $30^{\circ} \mathrm{NNE}$. The rock has a range of joints $\left(09^{\circ}-15^{\circ} \mathrm{NNE}\right)$, which are almost parallel to the strike of the rock $\left(46^{\circ} \mathrm{NE}\right.$ $-226^{\circ} \mathrm{SSW}$ ). The rock is very dark in colour. The high biotite composition of the rock makes it easily susceptible to weathering due to the high rate at which the rock absorbs heat from the sun. It has a medium to fine grain size. The rock is highly foliated and the folds form a sharp contact with the porphyritic granite rock bordering it (Figure $7 \mathrm{a}$ and $7 \mathrm{~b}$ ) 

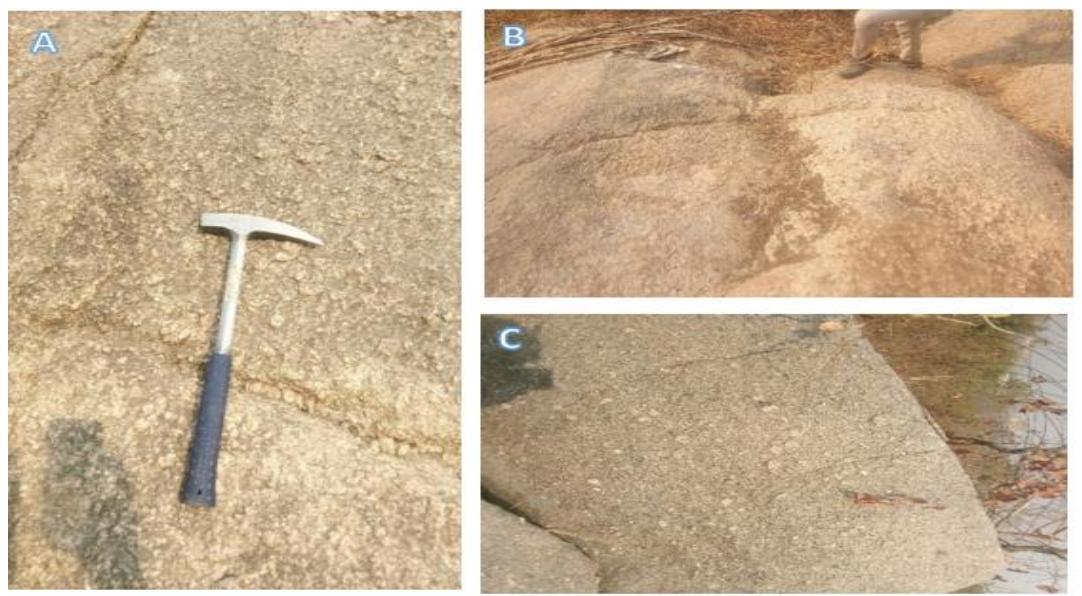

Figure 2: Plates of Porphyritic Granite rocks showing(a) A NE-SW trending Quartz vein intrusion (Location2: GPS; N 07041 20"; E $006^{\circ} 44^{\prime} 15.4^{\prime \prime)}$. (b) A domed shape Porphyritic Granite (Location 1: N $07^{\circ} 41^{\prime} 10.8^{\prime \prime}$ E E 006 44 5.4"). (c) An isolated porphyritic granite (Location 5: N $07^{\circ} 41^{\prime} 4$ "E 006 $\left.44^{\prime} 30.5 "\right)$.

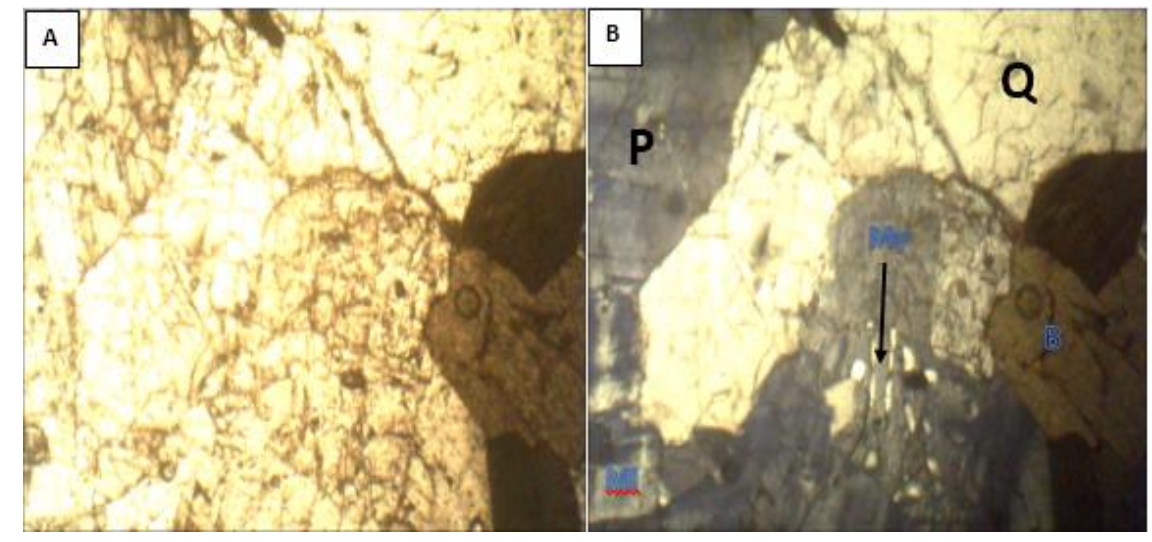

Figure 3: (Slide T2), A photomicrograph of porphyritic granite (a) under a plain polarized light. (b) Essential mineral composition under XPL. Q=quartz, My=Myrmekitic texture, $\mathrm{P}=$ plagioclase, $\mathrm{B}=$ Biotite and Mi=Microcline. ( $\times 20)$.

The structures observed on the outcrop include quartzo-feldspartic intrusions, folds, joints, foliations and veins. From hand specimen, $60 \%$ of the rock is leucocratic while the remaining $40 \%$ is melanocratic. The dominant mineral assemblage of the rock include quartz $(41.9 \%)$, Sanidine (0.4\%), Microcline (3.4\%), biotite $(30.8 \%)$, Muscovite $(7.7 \%)$, Hornblende $(2.6 \%)$, Plagioclase (8.5\%) and Opaque Minerals (4.7\%) (Figure 8). 


\section{Nigerian Journal of Basic and Applied Science (December, 2021), 29(2):46-58}
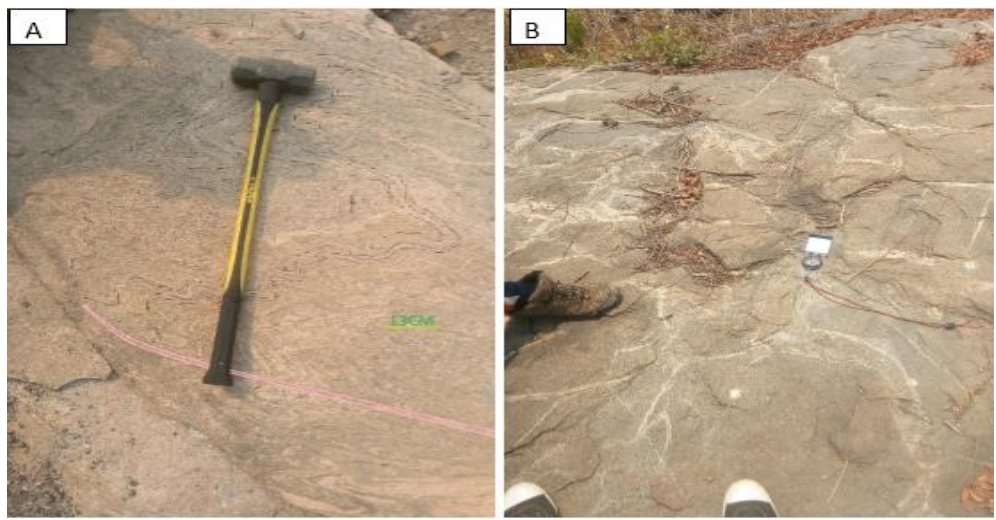

Figure 4: Platesshowing (a) ptygmatic folds and quartz vein intrusion (Location 6: N 070 41' 47.8" and $\left.\mathrm{E} 006^{\circ} 44^{\prime} 04.3^{\prime \prime}\right)$, (b) low lying migmatitic gneiss rock with deformed quartz vein in different direction (Location9: N 070 41' 43.0" and E 006०44'20").
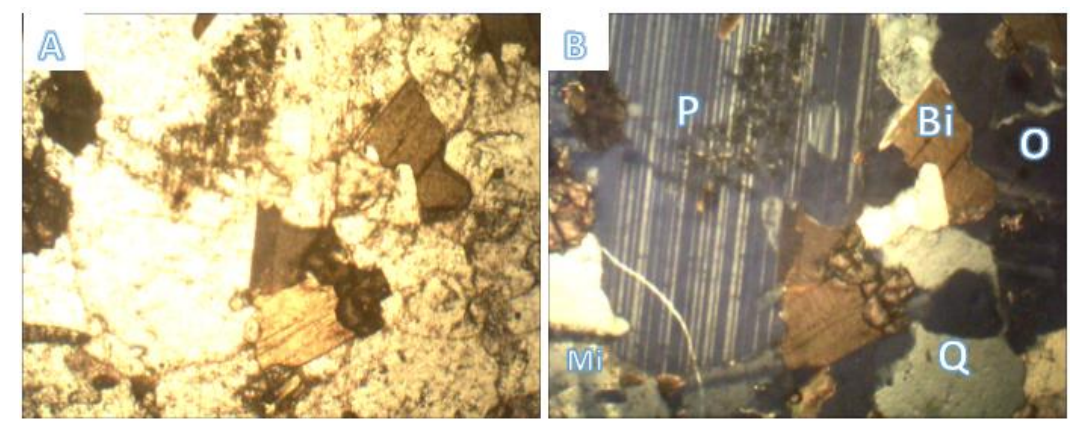

Figure 5: (Slide T9). A photomicrograph of migmatitic gneiss (a) Under PPL. (b) Essential mineral composition under XPL include; $\mathrm{Q}=$ quartz, $\mathrm{P}=$ plagioclase, $\mathrm{Bi}=$ Biotite, $\mathrm{O}=$ Opaque minerals and Mi=Microcline. $(x 20)$.

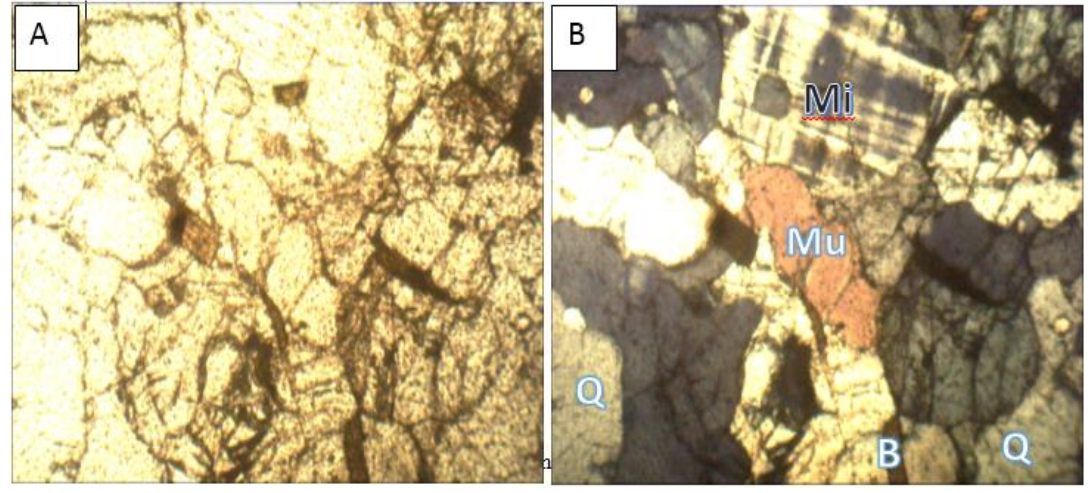

Figure 6: (Slide T6). A photomicrograph of migmatitic gneiss (A) under PPL. (B) Photomicrograph of migmatitic gneiss showing essential mineral composition under XPL. Q=quartz, Bi=Biotite, Mu= Muscovite and Mi=Microcline. (x20). 


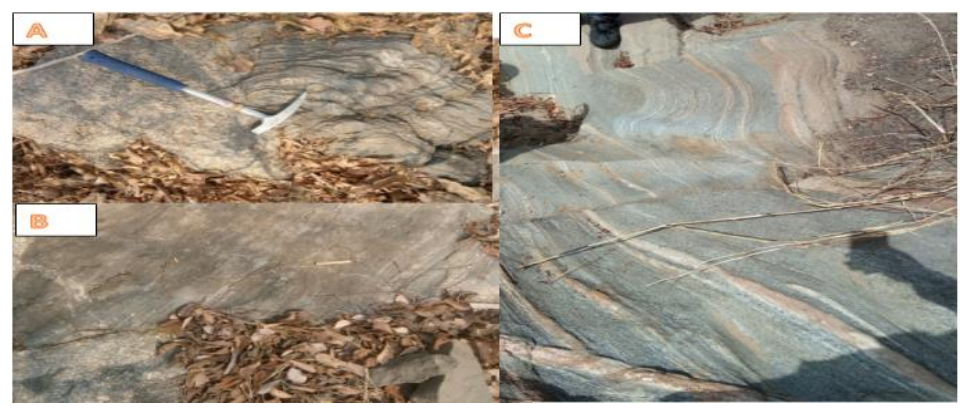

Figure 7: Plates of (a). A folded biotite gneiss rock forming a boundary with a porphyritic granite (Location 8a: N $07041^{\prime} 30.1^{\prime \prime}$ and E 0060 44' 14.5”), (b) A foliated Biotite Gneiss (Location 8b: N 070 $41^{\prime} 31.1^{\prime \prime}$ and $\left.E 006^{\circ} 44^{\prime} 15^{\prime \prime}\right)$, (c) A foliated and more felsic biotite gneiss rock forming boundary with the Migmatite Gneiss (Location 7: N $07041^{\prime} 26.1^{\prime \prime}$ and E 006 44' 5.4").

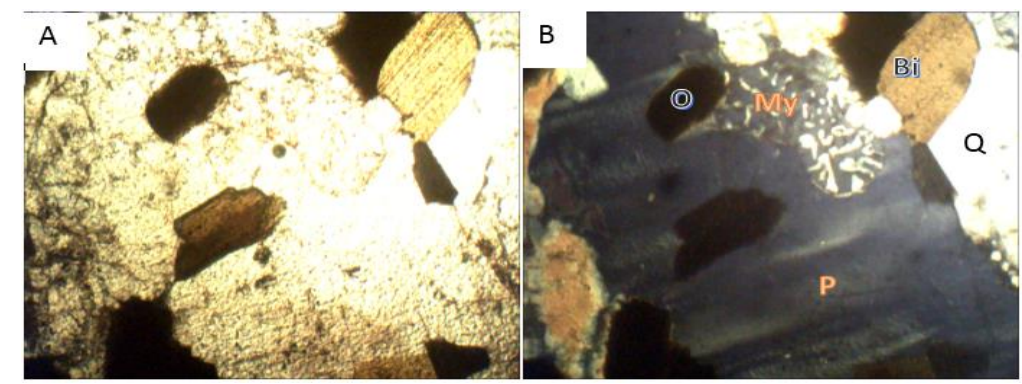

Figure 8: A photomicrograph of biotite gneiss (a) under PPL. (b) Showing mineral composition under XPL. Q=quartz, Bi=Biotite, $\mathrm{O}=$ Opaque Minerals, $\mathrm{My}=$ Myrmekitic texture and $\mathrm{P}=P$ Plagioclase. $(\mathrm{x} 20)$.

\section{Granite Gneiss}

The granite gneiss occurs in areas along Salem University Lokoja, Ajaokuta Road and the rocks trending in 32NE-SW direction (Figure 1). The texture of these rocks varies from medium to coarse grains and foliated with thin-bands of light

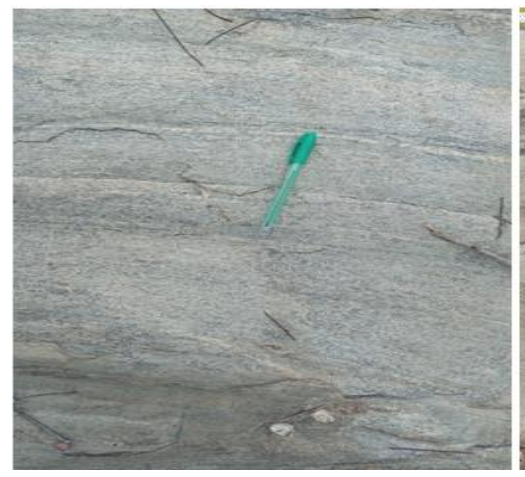

to dark colour minerals (Figure 9). The dominant mineral assemblages found in the granite-gneiss include quartz $(57.9 \%)$, plagioclase $(20 \%)$, biotite $(14.7 \%)$, microcline $(15 \%)$ and others $(10 \%)$ (Figure 10) and the structures observed on the outcrop are folds, joints, veinlets and quartz veins.

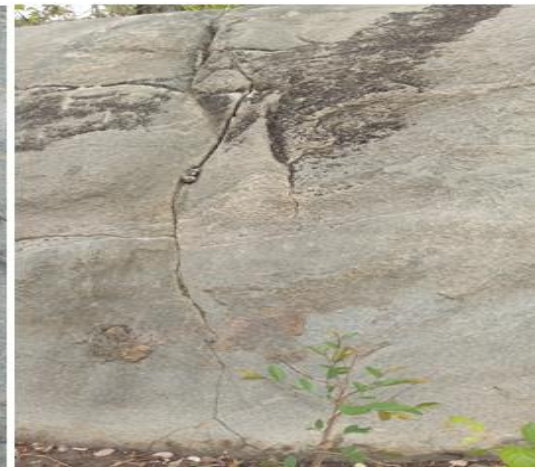

Figure 9: Plates of the banded gneisses found within Salem University (a) Location B3: N070 41' 51" E006॰ 43' 50" (b) Location N070 41' 42" E006॰ 43' 50". 


\section{Nigerian Journal of Basic and Applied Science (December, 2021), 29(2):46-58}

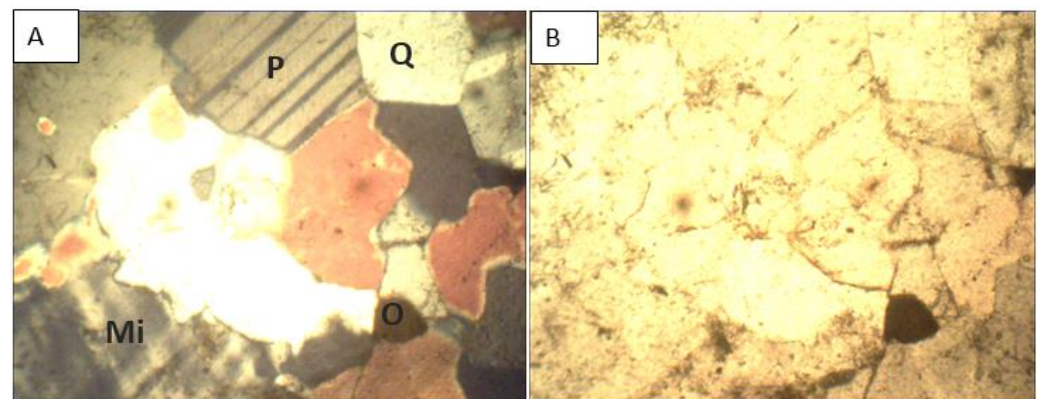

Figure 10: (A) A photomicrograph of a banded gneiss showing some common rock forming minerals under $\mathrm{XPL}, \mathrm{Q}=\mathrm{Quartz}, \mathrm{P}=$ Plagioclase, Mi=Microcline, $\mathrm{O}=0$ paque minerals. (B) $\mathrm{A}$ photomicrograph of a Banded Gneiss showing $85 \%$ felsic minerals and $15 \%$ mafic minerals under PPL.

From the modal composition of each of the samples of the rock analyzed, quartz which is a common rock forming mineral has the highest percentage with an average of $45.68 \%$ (Table 1). This shows that the rocks are extrusive and must have occurred from melting of crustal rocks. The quartz in all the rock samples analyzed are polysynthetic. The quartz content of the migmatitic gneiss increases towards the northern part of the study area, this gives a more felsic migmatitic gneiss and therefore, it will be more resistant to weathering. The plagioclase all together is averagely $11.44 \%$, on the porphyritic granite (Table 1), calcium dominates the plagioclase in the porphyritic granite and thus validate the QAP plot where the sample plots in the granodioritic field of the QAP diagram (Figure 11) while Sodium dominates the plagioclase in the migmatitic gneiss and the biotite gneiss as it shows a thin band in Figure 5 .

Generally, the biotite content of each of these rock samples are relatively moderate except in the biotite gneiss where it hits an average of about $31 \%$ (Table 1). This gives the rock a higher susceptibility to weathering and it also makes the rock less useful for construction works. The rocks having the moderately low percentage of ferromagnesian i.e. biotite, hornblende makes it a good to excellent material for construction work. Based on the rock types we have within the study area, the porphyritic granite and the migmatitic gneiss are good for construction but the migmatitic gneiss is the best for construction because of its fine to medium grain size. The smaller the grain size of any rock, the less susceptible it is to weathering. Structural imprints (Figure 4,7,9) on the rocks shows a lot about the tectonic episodes that the rocks have been subjected to. The common fault types are dextral strike-slip faults and Normal faults, this reveals that there has been an extensional force that led to the breakage; thus, displacing the rocks relative to each other. The strike slip faults indicate a trans-current tectonic regime. The complex folds encountered on the migmatitic gneiss rocks shows compressional forces coming from the limbs of these folds. The ptygmatic folds occur due to flowage in different directions, the flow of these partially melted rocks was in response to gravity. The joints are also trending NE-SW and NW-SE directions, the joints that is parallel to the rock trend can be said to be syntectonic while the joints that are perpendicular to the rock trend must have occurred after the rock was emplaced. The minor rocks include pegmatite which occurs in form of quartzofeldspartic intrusion and quartz vein. The quartzofeldspartic intrusions are majorly trending $285^{\circ}$ to $300^{\circ}$ (NW- SE) direction while the quartz vein also trends NE-SW direction, they are mostly crosscutting the rocks trend. These characteristics as evident on the rocks in the study area indicate imprints of the Pan-African orogeny. 
Adamu et al. Geology, Geochemistry and Petrogenetic Studies of the Precambrian...

Table 1: Average mineral modal compositions of rocks from thin section analysis of rocks from area around Jimgbe

\begin{tabular}{llllll}
\hline $\begin{array}{l}\text { ROCK } \\
\text { TYPES/MINERALS }\end{array}$ & $\begin{array}{l}\text { PORPHYRITIC } \\
(\%)\end{array}$ & $\begin{array}{l}\text { MIGMATITE } \\
\text { GNEISS (\%) }\end{array}$ & $\begin{array}{l}\text { BIOTITE } \\
\text { GNEISS (\%) }\end{array}$ & $\begin{array}{l}\text { GRANITE } \\
\text { GNEISS (\%) }\end{array}$ & $\begin{array}{l}\text { AVERAGE } \\
(\%)\end{array}$ \\
\hline QUARTZ & 39.91 & 43.10 & 41.90 & 57.80 & 45.68 \\
PLAGIOCLASE & 13.20 & 14.05 & 8.50 & 10.00 & 11.44 \\
ORTHOCLASE & - & 0.60 & - & - & 0.15 \\
MICROCLINE & 14.30 & 11.85 & 3.40 & 8.10 & 9.41 \\
SANIDINE & - & 0.30 & 0.40 & 0.10 & 0.20 \\
BIOTITE & 11.69 & 14.80 & 30.80 & 14.00 & 17.82 \\
MUSCOVITE & 8.00 & 7.45 & 7.70 & 6.10 & 7.31 \\
HORNBLENDE & 7.40 & 5.00 & 2.60 & 2.70 & 4.43 \\
OPAQUE & 5.50 & 2.85 & 4.70 & 1.20 & 3.56 \\
TOTAL AVERAGE & 100 & 100 & 100 & 100 & 100 \\
\hline
\end{tabular}

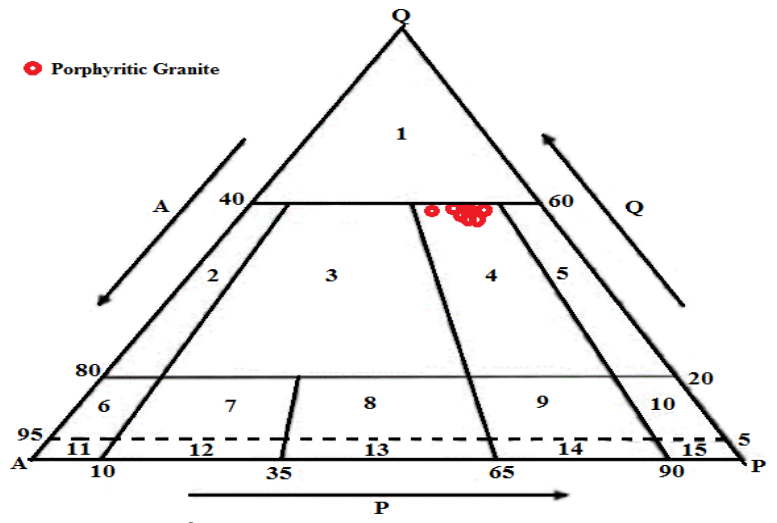

Figure 11: The QAP diagram for the granitic rocks in aera around SE of Jimgbe (Streckeisen, 1976). 1=Quartzolite; 2=Alkali Granite; 3=Granite; 4=Granodiorite; $5=$ Tonalite; 6=Alkali Quartz Syenite; 7=Quartz Syenite; 8=Quartz Monzonite; $9=$ Quartz Monzodiorite; 10=Quartz Diorite; 11=Alkali Syenite; 12=Syenite; 13=Monzonite; 14=Monzodiorite; 15=Diorite.

\section{Geochemical Characterization}

The geochemical results for the major oxides are presented in Table 2. The $\mathrm{SiO}_{2}$ content in porphyritic granite was 69 wt. $\%, \mathrm{Al}_{2} \mathrm{O}_{3}(14 \%$ wt. $\%), \mathrm{CaO}\left(5.6 \%\right.$ wt.\%) and $\mathrm{Na}_{2} \mathrm{O}$ was 2.70 wt. $\%$, while $\mathrm{MgO}$ content was $2.20 \mathrm{wt} . \%$. The $\mathrm{k}_{2} \mathrm{O}$ content was 4.20 wt. $\%, \mathrm{Fe}_{2} \mathrm{O}_{3}$ was 1.80 wt. \%, $\mathrm{P}_{2} \mathrm{O}_{5}$ was 0.50 wt. $\%$, while $\mathrm{MnO}$ and $\mathrm{TiO}_{2}$ were 0.10 wt. \% each while the $\mathrm{SiO}_{2}$ content of the biotite gneisses ranges from 68 to 71.3 wt.\%, $\mathrm{Al}_{2} \mathrm{O}_{3}$ from 0.9 to $14 \%$ wt.\%, $\mathrm{CaO}$ from 5.0 to $5.4 \%$ wt. $\%, \mathrm{Na}_{2} \mathrm{O}$ was 3.1 to 3.9 wt. \%, while $\mathrm{MgO}$ content was 2.80 to 3.1 wt. $\%$. The $\mathrm{k}_{2} \mathrm{O}$ content ranges 2.7 to 4.10 wt. $\%, \mathrm{Fe}_{2} \mathrm{O}_{3}$ was 1.70 wt. $\%$ each, $\mathrm{P}_{2} \mathrm{O}_{5}$ was 0.30 to 0.60 wt. $\%, \mathrm{MnO}$ rages from 0.2 to 0.5 wt. $\%$ and $\mathrm{TiO}_{2}$ was from 0.30 to 0.40 wt. \% (Table 2). The high content of the $\mathrm{SiO}_{2}$ in the granite is an indication of the acidic nature and enrichment in common rock forming minerals such as quartz and feldspar.

The variation diagram of $\mathrm{SiO}_{2}$ against other major oxides according to Harkar (1909) shows a strong negative correlation between $\mathrm{SiO}_{2}$ versus $\mathrm{Al}_{2} \mathrm{O}_{3}$, $\mathrm{CaO}, \mathrm{MgO}$ and $\mathrm{K}_{2} \mathrm{O}$ (Figure 12). This means that as the $\mathrm{SiO}_{2}$ content increases, $\mathrm{Al}_{2} \mathrm{O}_{3}, \mathrm{CaO}, \mathrm{MgO}$, and $\mathrm{K}_{2} \mathrm{O}$ decreases. $\mathrm{P}_{2} \mathrm{O}_{5}$ and $\mathrm{N}_{2} \mathrm{O}$ against $\mathrm{SiO}_{2}$ plot indicates a positive correlation while $\mathrm{Fe}_{2} \mathrm{O}_{3}$ shows no correlations at all. The discrimination diagram of $\mathrm{Na}_{2} \mathrm{O}_{/} \mathrm{Al}_{2} \mathrm{O}_{3}$ against $\mathrm{K}_{2} \mathrm{O} / \mathrm{Al}_{2} \mathrm{O}_{3}$ (Figure 


\section{Nigerian Journal of Basic and Applied Science (December, 2021), 29(2):46-58}

13a) shows that the porphyritic granite and sample T4 of the biotite gneiss are of igneous origin while sample $\mathrm{T} 11$ of the biotite gneiss plots in the metasedimentary field (Garrel and McKenzie, 1971). The $\mathrm{TiO}_{2}-\mathrm{K}_{2} \mathrm{O}-\mathrm{P}_{2} \mathrm{O}_{5}$ diagram shows that the granite and the gneisses were emplaced in a continental environment, this must have been the reason that accounts for the high $\mathrm{SiO}_{2}$ and $\mathrm{Al}_{2} \mathrm{O}_{3}$ contents (Pierce et al., 1975) (Figure 13b). $\mathrm{CaO}-\mathrm{N}_{2} \mathrm{O}-\mathrm{K}_{2} \mathrm{O}$ diagram shows that the porphyritic granite is quartz diorite to granodiorite which is in agreement with the result from the QAP diagram (Figure 11) (Condie, 1967) (Figure 14a).

The molecular plot of $\mathrm{Al}_{2} \mathrm{O}_{3} /\left(\mathrm{Na}_{2} \mathrm{O}+\mathrm{K}_{2} \mathrm{O}\right)$ against $\mathrm{Al}_{2} \mathrm{O}_{3} /\left(\mathrm{CaO}+\mathrm{Na}_{2} \mathrm{O}+\mathrm{K}_{2} \mathrm{O}\right)$ (Figure 16) shows that the porphyritic granite and sample T4 of the biotite gneiss are peraluminous rocks, this means that that $\mathrm{Al}_{2} \mathrm{O}_{3}>\left(\mathrm{CaO}+\mathrm{Na}_{2} \mathrm{O}+\mathrm{K}_{2} \mathrm{O}\right)$; thus, indicating the high content of Alumina in the rocks, Slide T11 plots in the metaluminous field $\mathrm{Al}_{2} \mathrm{O}_{3}<\left(\mathrm{CaO}+\mathrm{Na}_{2} \mathrm{O}+\mathrm{K}_{2} \mathrm{O}\right)$. The peraluminous and slightly metaluminous nature of the rocks are indications of an igneous protolith (Maniar et al., 1989) (Figure 14b). The plot of $\mathrm{Al}_{2} \mathrm{O}_{3} /$ $\left(\mathrm{CaO}+\mathrm{Na}_{2} \mathrm{O}+\mathrm{K}_{2} \mathrm{O}\right)$ against $\mathrm{SiO}_{2}$ further classify the porphyritic granite and sample T4 of the biotite gneiss to be an S-type peraluminous rock (Dombrowski et al., 1995) (Figure 15a). The $\mathrm{MgO}-\mathrm{CaO}-\mathrm{Al}_{2} \mathrm{O}_{3}$ diagram of Leyleroup et al. (1977) shows that the porphyritic granite and the biotite gneisses are magmatic rocks (Figure 15b). $\mathrm{K}_{2} \mathrm{O}$ versus $\mathrm{N}_{2} \mathrm{O}$ discrimination diagram shows that the porphyritic granite and sample T11 of the biotite gneiss plots in the eugeosynclinal field which indicates that their protolith are sedimentary rocks while sample $\mathrm{T} 4$ of the biotite gneiss plots outside the eugeosynclinal field, indicating a magmatic protolith (Middleton, 1960) (Fig 16a). Plot $\mathrm{Na}_{2} \mathrm{O}+\mathrm{K}_{2} \mathrm{O}$ against $\mathrm{SiO}_{2}$ indicate that the porphyritic granite and the biotite gneisses are Sub-alkaline rocks (Irvine and Baragar, 1971) (Figure 16b). Finally, $\mathrm{K}_{2} \mathrm{O}$ versus $\mathrm{SiO}_{2}$ plot shows that the porphyritic granite is medium K-Calc Alkaline rock while the biotite gneisses are high K-Calc Alkaline rocks (Rickwood, 1989) (Figure17).

\section{Conclusion}

The geochemical and geological characteristics of the Basement Complex rocks in SE Jimgbe area belong to the Southwestern Basement Complex rock of Nigeria. Petrographic, field relationship records and geochemical correlations results give a good match, suggesting the rocks are granitic in origin. The tectonic imprints on the major and minor rocks show signatures of the Pan-African Orogeny probably terminated by intrusions events such as quartzo-feldspartic which occurred as fracture fillings and quartz vein imprints on these rocks.

\section{REFERENCES}

Adegbuyi, O., Ogunyele, A. C., \& Akinyemi, O. M. (2018). Petrology and Geochemistry of Basement Gneissic Rocks around OkaAkoko, Southwestern Nigeria. Malaysian Journal of Geosciences, 2(2):11-16.

Akindele, O. O. (2011): Geology and Geotectonic Setting of the Basement Complex Rock in South Western Nigeria: Implications on Provenance and Evolution, Earth and Environmental Sciences, Dr. Imran Ahmad Dar (Ed.), ISBN: 978-953-307468-9. 
Adamu et al. Geology, Geochemistry and Petrogenetic Studies of the Precambrian...

Table 2: Average percentage oxide values of major element compositions from XRF analysis of the rock types around Jimgbe

\begin{tabular}{|c|c|c|c|c|c|c|c|}
\hline \multirow[t]{2}{*}{ MAJOR OXIDES } & \multicolumn{2}{|c|}{$\begin{array}{l}\text { PORPHYRITIC } \\
\text { GRANITE }\end{array}$} & \multicolumn{2}{|c|}{ BIOTITE GNEISS } & \multirow{2}{*}{$\begin{array}{l}\text { GRANITE } \\
\text { GNEISS } \\
\text { B9 } \\
\mathrm{N}=4\end{array}$} & \multirow{2}{*}{$\begin{array}{l}\text { MIGMATITIC } \\
\text { GNEISS } \\
\text { B6 } \\
\mathrm{N}=4\end{array}$} & \multirow{2}{*}{$\begin{array}{l}\text { AVERAGE } \\
(\%)\end{array}$} \\
\hline & $\begin{array}{l}\mathrm{T} 2 \\
\mathrm{~N}=4\end{array}$ & $\begin{array}{l}\text { B3 } \\
N=4\end{array}$ & $\begin{array}{l}\mathrm{T} 4 \\
\mathrm{~N}=4\end{array}$ & $\begin{array}{l}T 11 \\
N=4\end{array}$ & & & \\
\hline $\mathrm{SiO}_{2}$ & 69.00 & 69.12 & 68.00 & 71.30 & 66.75 & 71.34 & 69.25 \\
\hline $\mathrm{Al}_{2} \mathrm{O}_{3}$ & 14.00 & 12.63 & 14.00 & 10.89 & 11.60 & 11.34 & 12.41 \\
\hline $\mathrm{CaO}$ & 5.50 & 5.16 & 5.40 & 5.00 & 7.49 & 5.74 & 5.72 \\
\hline $\mathrm{Na}_{2} \mathrm{O}$ & 2.700 & 3.79 & 3.80 & 3.10 & 3.63 & 2.53 & 3.25 \\
\hline MgO & 2.20 & 1.89 & 3.10 & 2.80 & 3.23 & 3.42 & 2.76 \\
\hline $\mathrm{K}_{2} \mathrm{O}$ & 4.20 & 4.21 & 2.70 & 4.10 & 4.21 & 3.15 & 3.76 \\
\hline $\mathrm{Fe}_{2} \mathrm{O}_{3}$ & 1.80 & 1.84 & 1.70 & 1.70 & 1.66 & 1.94 & 1.77 \\
\hline $\mathrm{P}_{2} \mathrm{O}_{5}$ & 0.50 & 0.54 & 0.30 & 0.60 & 0.49 & 0.37 & 0.47 \\
\hline $\mathrm{MnO}$ & 0.10 & 0.29 & 0.50 & 0.20 & 0.41 & 0.50 & 0.33 \\
\hline $\mathrm{TiO}_{2}$ & 0.10 & 0.38 & 0.35 & 0.30 & 0.26 & 0.26 & 0.28 \\
\hline Total Average & & & & & & & 100.00 \\
\hline $\mathrm{Na}_{2} \mathrm{O} / \mathrm{Al}_{2} \mathrm{O}_{3}$ & 0.20 & 0.30 & 0.28 & 0.28 & 0.31 & 0.22 & \\
\hline $\mathrm{K}_{2} \mathrm{O} / \mathrm{Al}_{2} \mathrm{O}_{3}$ & 0.31 & 0.35 & 0.19 & 0.38 & 0.36 & 0.28 & \\
\hline $\mathrm{K}_{2} \mathrm{O} / \mathrm{Na}_{2} \mathrm{O}$ & 1.56 & 1.56 & 0.69 & 1.32 & 0.69 & 1.32 & \\
\hline $\mathrm{Al}_{2} \mathrm{O}_{3} /\left(\mathrm{Na}_{2} \mathrm{O}+\mathrm{K}_{2} \mathrm{O}\right)$ & 2.03 & 13.30 & 2.12 & 1.51 & 13.00 & 14.1 & \\
\hline $\mathrm{Al}_{2} \mathrm{O}_{3} /\left(\mathrm{CaO}+\mathrm{Na}_{2} \mathrm{O}+\mathrm{K}_{2} \mathrm{O}\right)$ & 1.20 & 10.40 & 1.17 & 0.89 & 9.30 & 7.70 & \\
\hline $\mathrm{K}{ }_{2} \mathrm{O}+\mathrm{NaO}-\mathrm{CaO}$ & 1.30 & 1.30 & 1.20 & 2.20 & 1.20 & 2.20 & \\
\hline $\mathrm{K}_{2} \mathrm{O}+\mathrm{NaO}$ & 6.90 & 8.00 & 6.60 & 7.20 & 7.80 & 5.70 & \\
\hline
\end{tabular}
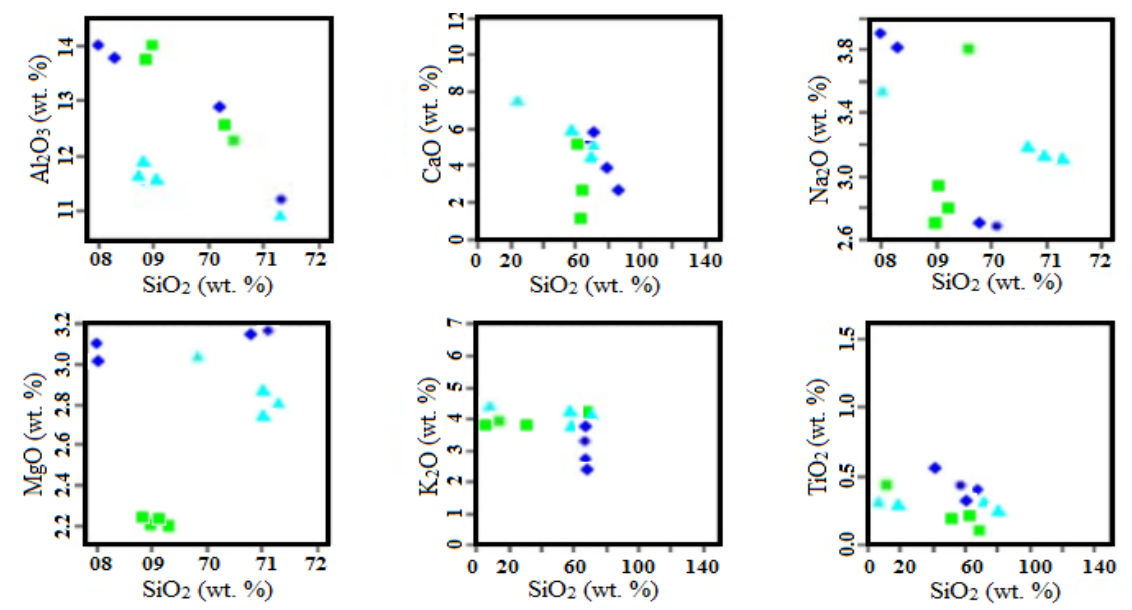

= Migmatite gneiss

- Porphyritic granite

A Biotite gneiss
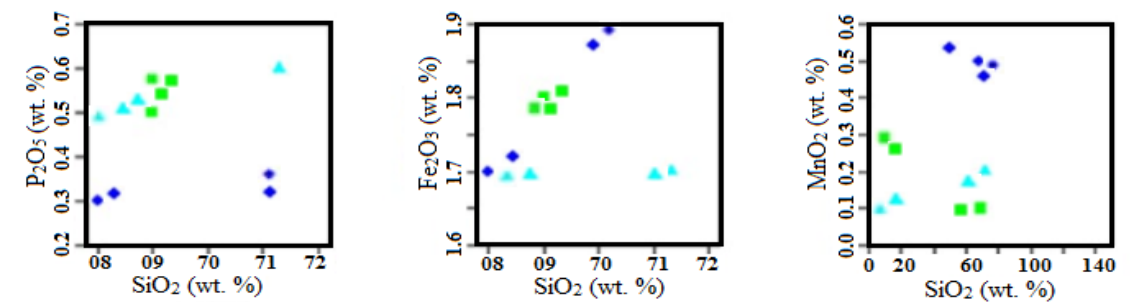

Figure 12: Variation of $\mathrm{SiO}_{2}$ against other major oxides within the study area 


\section{Nigerian Journal of Basic and Applied Science (December, 2021), 29(2):46-58}
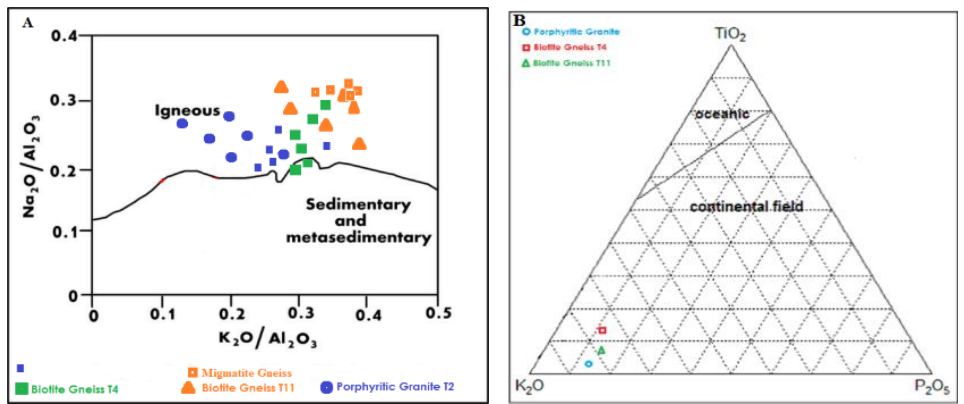

Figure 13: (a) $\mathrm{Na}_{2} \mathrm{O} / \mathrm{Al}_{2} \mathrm{O}_{3}$ versus $\mathrm{K}_{2} \mathrm{O} / \mathrm{Al}_{2} \mathrm{O}_{3}$ discrimination diagram for $\mathrm{SE}$ Jimgbe basement rocks (b) $\mathrm{TiO}_{2}-\mathrm{K}_{2} \mathrm{O}-\mathrm{P}_{2} \mathrm{O}_{5}$ diagram of rocks from South Eastern Jimgbe area.
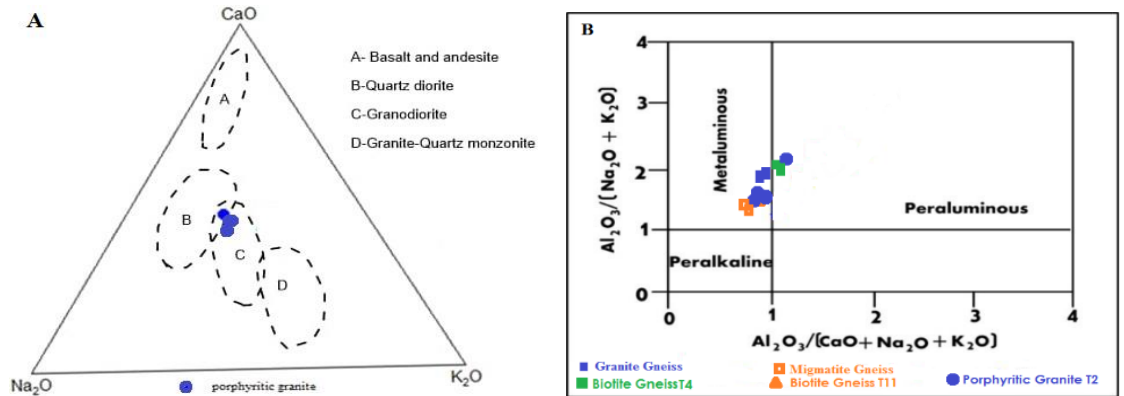

Figure 14: (a) $\mathrm{CaO}-\mathrm{Na}_{2} \mathrm{O}-\mathrm{K}_{2} \mathrm{O}$ ternary diagram of the rocks in $\mathrm{SE}$ Jimgbe area, (b) $\mathrm{Al}_{2} \mathrm{O}_{3} /\left(\mathrm{Na}_{2} \mathrm{O}\right.$ $\left.+\mathrm{K}_{2} \mathrm{O}\right)$ versus $\mathrm{Al} 2 \mathrm{O} 3 /\left(\mathrm{CaO}+\mathrm{Na}_{2} \mathrm{O}+\mathrm{K}_{2} \mathrm{O}\right)$ molecular plot for rocks in SE Jimgbe area.
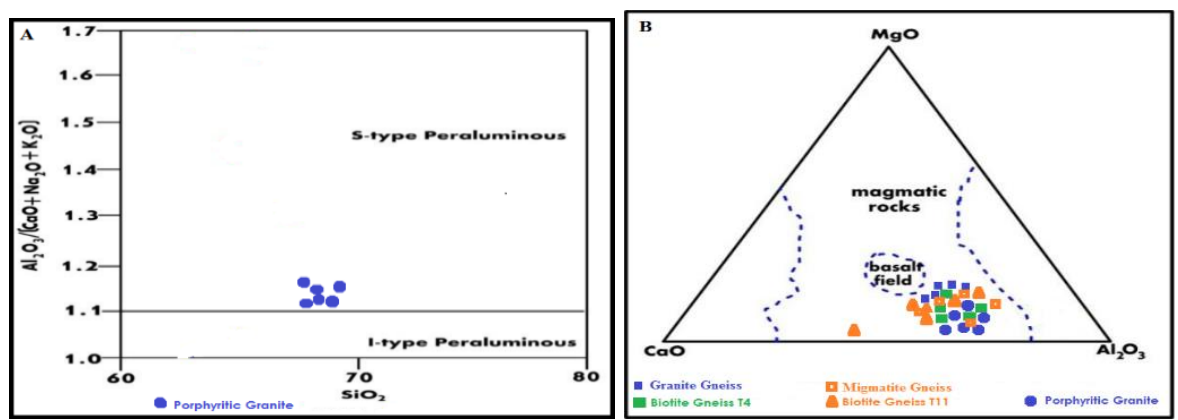

Figure 15: (a) $\mathrm{Al}_{2} \mathrm{O}_{3} /\left(\mathrm{CaO}+\mathrm{Na}_{2} \mathrm{O}+\mathrm{K}_{2} \mathrm{O}\right)$ versus $\mathrm{SiO}_{2}$ plot of rocks within $\mathrm{SE}$ Jimgbe area, (b) $\mathrm{MgO}$ $-\mathrm{CaO}-\mathrm{Al}_{2} \mathrm{O}_{3}$ diagram for rocks in $\mathrm{SE}$ Jimgbe area.
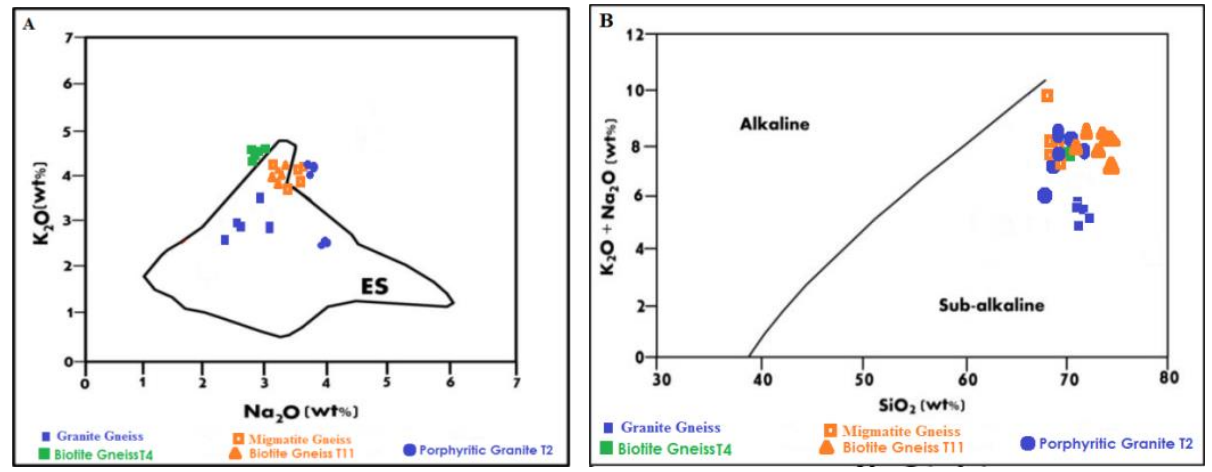

Figure 16: (a) $\mathrm{K}_{2} \mathrm{O}$ versus $\mathrm{Na}_{2} \mathrm{O}$ discrimination diagram for rocks in $\mathrm{SE}$ Jimgbe area, (b) $\mathrm{Na}_{2} \mathrm{O}+$ $\mathrm{K}_{2} \mathrm{O}$ against $\mathrm{SiO}_{2}$ Plot for SE Jimgbe area 
Adamu et al. Geology, Geochemistry and Petrogenetic Studies of the Precambrian...

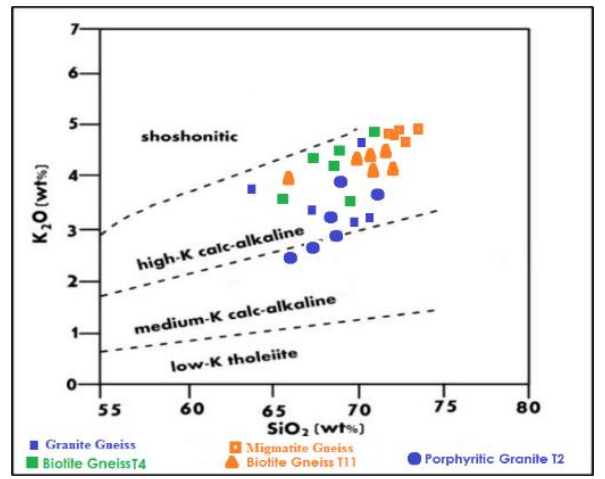

Figure 17: $\mathrm{K}_{2} \mathrm{O}$ versus $\mathrm{SiO}_{2}$ plot for rocks in SE Jimgbe area (Rickwood, 1989).

Dombrowski, A., Henjes-Kunst, F., Hohndorf, A., Kroener, A., Okrusch, M., and Richter, P. (1995): Orthogneisses in the Sperssart Crystalline Complex, north-west Bavaria: Silurian granitoidmagma-tism at an active continental margin. Geologische Rundschau, 84: 399-411.

Folorunso A. F., Ayolabi E. A., and Ariyo, S. 0. (2013): Geological mapping, petrology study and structural analysis of Precambrian basement complex rocks in part of AgoIwoye Southwestern Nigeria. International Research Journal of Geology and Mining, 3(1): 19-30.

Garrel, R. M., \& Mackenzie, F.T. (1971): Evolution of Sedimentary Rocks. W.W Norton and Co. Int. New York, p 394.

Gideon Y. B., (2019): Petrography and Geochemical characterization of Basement rocks within Okene metropolis, North Central Nigeria. International Journal of Geology, Earth \& Environmental Sciences, 9 (2):36-48.

Goki, N. G., Amadi, A. N., Amuneni, O., Agbo, P., Okoye, N. O. and Unuevho, C. I. (2011). Bulk strain estimation on gneisses in Central Nigeria: A preliminary assessment, Journal of Engineering and Technology Research, 3(4): 133-138.

Harker A. (1909). The natural history of igneous rocks. Methuen \& Co. London.

Irvine, T. N., \& Baragar, W. R. A. (1971): A guide to the chemical classifications of the common volcanic rocks. Canada Journal Earth Science, 8:523-548.

Leyleroup, A., Duppy, C., \& Andriambolona, R. (1977): Chemical composition and consequence of the evolution of the French Massif Central Precambrian crust.
Contributions to Mineralogy and Petrology, 62: 283-300.

Maniar, P. D., \& Piccoli, P. M. (1989): Tectonic discrimination of granitoids. Geological Society of America Bulletin, 101:635-643.

Middleton, E. V. (1960): Chemical Composition of Sandstone. Bull. Geol. Soc. of America, 71: 1011-1026.

Ogunyele, A. C., Obaje, S. O., Akingboye, A. S. (2018). Lithostructural Relationships and Petrogenetic affinities of the Basement Complex rocks around Okpella, Southwestern Nigeria, Earth Sciences Malaysia (ESMY), 2(1): 29-36

Olatunji, J. A., Imasuen, O. I., \& Onyeobi, T. (2013): Geological observations of basement rocks, around Ganaja, Kogi State, Nigeria. International Research Journal of Geology and Mining, 3(2):57-66.

Olusiji S. A. (2015). The Geology, Geochemistry and Petrogenetic Studies of the Precambrian Basement Rocks around Iworoko, Are and Afao Area, Southwestern Nigeria, Journal of Geology \& Geophysics, 4(4): 212.

Onimisi, M., Obaje N. G., \& Daniel, A. (2013). Field geologic occurrence and petrographic characteristics of Precambrian marble body in Itobe area, Central Nigeria. Advances in Applied Science Research, 4(5):58-71.

Rickwood, P. C. (1989): Boundary lines within petrologic diagrams which use oxides of major and minor elements. Lithos, International Journal of Petrology, Mineralogy and Geochemistry, 22: 247-263.

Streckeisen, A.L (1976). To each plutonic rock its proper name. Earth Science reviews, 12(1):1-33. 